\title{
Correlating Graduate Marketability Dimensions with the Measurements of University-Student Relationship
}

\author{
Chang Peng Kee ${ }^{1}$, Fauziah Ahmad ${ }^{1}$, Faridah Ibrahim $^{1} \&$ Kho Suet Nie ${ }^{1}$ \\ ${ }^{1}$ School of Media and Communication Studies, Faculty of Social Sciences and Humanities, Universiti \\ Kebangsaan Malaysia, Malaysia \\ Correspondence: Fauziah Ahmad, School of Media and Communication Studies, Faculty of Social Sciences and \\ Humanities, Universiti Kebangsaan Malaysia, 43600 Bangi, Selangor, Malaysia. Tel: 60-3-8921-4387, \\ 60-3-8921-4277. E-mail: zuhair@ukm.my
}

Received: October 28, $2011 \quad$ Accepted: December 15, $2011 \quad$ Published: May 1, 2012

doi:10.5539/ass.v8n6p63

URL: http://dx.doi.org/10.5539/ass.v8n6p63

This project is funded by the Ministry of Higher Education Malaysia under the research code: UKM-SK-05-FRGS0077-2009.

\begin{abstract}
Organization has always placed emphasis on the publics who would determine its life span. In the context of higher education institution, graduates are the main public whereby their marketability is the key measurement of a university's effort in the human resources development. Hon \& Grunig (1999) identify two types of organizational relationship from public perspectives. The communal relationship is said to focus more on the surrounding and balance effect whilst exchange relationship is more inclined towards organizational self interest from the viewpoint of the public. From a different perspective on these two types of relationship, what exactly is the correlation between the student's soft skills as claimed to be the determinant of their future employability after graduation? This problem has definitely tapped the interest of researchers to conduct an empirical study in order to examine the views of a university's final-year undergraduates regarding the relationship of university-student and relate it to the seven dimensions of soft skills, namely communication skills, critical and problem solving skills, teamwork skills, continuous learning and information management skills, entrepreneurship skills, professional moral and ethics as well as leadership skills. Perceptions from 115 students were studied through face-to-face survey method. Communal relationship was proven relationally positive with communication skills, critical and problem solving skills, teamwork skills, continuous learning and information management skills, and entrepreneurship skills while exchange relationship was inversely related with professional moral and ethics.
\end{abstract}

Keywords: public relations, organization-public relationship measurement, graduate marketability, soft skills, human resource development

\section{Introduction}

Surviving long in the environment, all organizations cannot deny due attention for the public who are influential to their life cycles. No matter where, in all higher learning institutions, graduates are the main public and their marketability is perceived as the key measurement of a university's effort in human resources development. In this context, graduates are seen as human capital, generated from the university's effort to increase manpower value for the work market. Graduates often carry the image that represents their alma mater's quality or the the image of the university where they once studied. Their success in employment or business after graduation will surely notch up the image for the institute as well as the educator who nurtured them. On the other hand, the failure of graduates will definitely affect the reputation of the institution where they received their formal edcuation.

Before graduation, a student should have built up their relationships with friends and the university where they studied. Hon \& Grunig (1999) identified two types of organizational relationship with publics from a certain public perception. Organization is said to pay more attention to surroundings and social welfare in communal relationship, whereas exchange relationship is more inclined to organizational self interest. 
Seltzer \& Mitrook (2009) once expanded the research in the measurement of both communal and exchange relationship to understand its public agreement in co-orientation relationship. What will be the progress from the measurement of both relationships in this research to examine graduate marketability of a public university? To evaluate the graduate success in the employment or business market, what indicator of university-student relationship, or in larger context, organization-public relationship, should be given due attention by policymaker to generate better graduate marketability? These are some pertinent questions that need to be addressed.

\section{Problem Statement and Research Objectives}

The importance of higher education in the process of national development cannot be underestimated. To remain competitive in the ever-changing market conditions, many governments need to produce value-added capabilities to the present and future human capital in order to stay viable in the global competition. A well-planned strategy in the education sector is considered important in today's environment where a massive human capital is located. The ability to transform this mass of human resource will be a prerequisite for a more knowledgeable and highly skilled human capital in the future.

Hence, the education sector is considered by both developed and developing nations to be a critical agenda in the process of national development and nation building. Many countries in the Asian region for instance China, South Korea and Singapore are already reinventing their leading institutions of higher education in order to meet the challenges by the competitive global market. Indeed, Malaysia, a neighboring country to Singapore cannot afford to lag behind. It is with this goal in mind that the higher education system in Malaysia has to undergo a transformation which is solely aimed at producing Malaysians who are intellectually active, creative, innovative, ethically and morally upright, adaptable and capable of critical thinking (Ministry of Higher Education Malaysia, 2007).

To improve the transformation process, a prerequisite that is considered compulsory to be implemented immediately in Malaysia's higher institutions is the focus on generic skills considered vital to produce a well-rounded and holistic human capital. Seven generic skills have been identified as the key-focus ever since the Ministry of Education introduced its action plan in 2007. The seven generic skills or popularly known as soft skills include communications skills, critical and problem-solving skills, teamwork skills, continuous learning and information management skills, entrepreneurship skills, professional moral and ethics, and leadership skills. The seven soft skills identified by the Malaysian Ministry of Higher Education synchronized with those suggested by prospective employers interviewed in a local nationwide study (see Faridah, Normah \& Mus Chairil 2010). The study identified analytical and critical thinking as one of the important skills that need to be imparted to universities' students before graduation apart from other critical elements namely strategic thinking, patriotism and innovativeness.

Apart from the soft skills, Hon \& Grunig (1999) introduced two dimensions that measure graduate marketability in order to stay competitive in the changing global market. From a different perspective on the two dimensions of the relationship, what is the correlation with its students' soft skills that are said to be the key factor to marketability upon graduation? This question prompted researchers to conduct a pilot study to understand the views of undergraduates of a public university regarding their perception on university-public relationship and in turn relates to seven dimensions of soft skills measurement that are communication skills, critical and problem solving skills, teamwork skills, continuous learning and information management skills, entrepreneurship skills, professional ethics and moral, and leadership skills.

This study involves the future graduates of the National University of Malaysia to find out the accuracy of organization-public relationship theory formed by Hon \& Grunig (1999) in measuring graduate marketability. In this relationship, this research intends to examine the viewpoints from the final-year undergraduate students of the said public university, i.e. National University of Malaysia in order to:

- identify how far the correlation is between students academic achievement and perception towards both communal and exchange relationships; and

- identify how far students academic achievement and perception towards communal and exchange relationships play a role in generating their marketability with the evaluation of soft skills level.

\section{Literature}

Public relations as a profession is proven to play an important role in management relationships that benefited all parties between organization and main publics (Cutlip, Center \& Broom, 1985). Chang \& Musa (2006) opined from their experience that it is important that public relations activities are measured by their economic 
measurement. Scholars in this field (such as Grunig, 1992; Huang, 2001; Ledingham \& Bruning, 2000) concurred there are indeed financial contribution from public relations efforts.

To help public relations practitioners measure their activities, especially in organization and certain public relationship, Hon \& Grunig (1999) suggested a guide to evaluate organization achievement with the introduction of Public Relations Measurement Scale. This scale was improved by other public relations scholar such as Grunig \& Huang (2000), Huang (2001), Kim (2001), and Samsup, Hon \& Brunner (2004). However, research regarding the measurement in Malaysia is still lacking, except for one comparative study conducted by Pendleton \& Kiranjit (2008).

The researchers believe that the Public Relations Measurement Scale has a high validity value. The measurement of organization-public relationship was originally created by Hon \& Grunig (1999), involving four independent variables, namely trust, satisfaction, commitment and control mutuality that are said to be the determinant to feelings that will shape the perception on communal and exchange relationships. Communal relationship stems from the assumption that both parties benefit each other because they care for the opposite party welfare, even though they may not gain anything in return. This concept is in line with the social responsibility that is very much applauded in the public relations profession. Meanwhile, exchange relationship is very much business scented, whereby one party benefits the other party because they had been given benefit in the past or are expected to receive some form of benefits in the future.

The earliest relationship between mankind is assumed to start from exchange concept that constantly tries to balance their input and output ratio. Exchange is something that happened in marketing relationship between organization and its customers or its public. The exchange relationship is also largely related to the social power that a superior organization has on its public and the way the superior organization approach the subordinates or public will affect the public satisfaction (Kim, 2008). However, the gap exist when the studies are focused on of the elements of the relationship namely satisfaction, hence a more holistic picture should be given into other elements of a relationship such as how these relationship will affect its public in the future.

Public relations practice is widely accepted as a management function that identifies, creates and maintains the organization relationships with its publics that will make or break the organization. This profession field involves planned communication effort that constantly taps on public opinion and create appropriate communication between publics and its organization in order to create the bond between publics and its organization.

In other words, two types of relationship from certain public perception can be identified in organization relationship with publics. The first will be communal relationship. In this relationship, organization is assumed to be doing something as charity even though they do not reap any benefit from their efforts. In this sense, organization is expected to give to the society even when the organization receives little or no benefit in return.

The constructs of communal relationship by Hon \& Grunig (1999, p. 30) are as follows:

- This organization does not especially enjoy giving others aid. (Reversed statement)

- This organization is very concerned about the welfare of people like me.

- I feel that this organization takes advantage of people who are vulnerable. (Reversed statement)

- I think that this organization succeeds by stepping on other people. (Reversed statement)

The second relationship is exchange relationship. In this relationship, an organization will only give to a public that will benefit them in return. Organization is perceived as taking care of the public that will bring benefit to the organization. This situation happened because the organization is expecting return by receiving benefits equal to their contribution.

The constructs of exchange relationship by Hon \& Grunig (1999, p. 30) are as follows:

- Whenever this organization gives or offers something to people like me, it generally expects something in return.

- $\quad$ Even though people like me have had a relationship with this organization for a long time, it still expects something in return whenever it offers us a favor.

- This organization will compromise with people like me when it knows that it will gain something.

- This organization takes care of people who are likely to reward the organization.

Researches on graduates as a public and its dynamic relationship with other entities are not new as graduates are often perceived as a very important entity of the society. For example, Fatemah et. al. (2010) studied the female 
graduates' perception of relationship between the residence hall and home. The researchers discovered that physical facilitates and comfort, security, privacy, warmth and friendly environment are four recurring themes for the female graduates to feel at home in the residence hall.

With regard to graduate marketability, nearly all higher learning institute in Malaysia implemented soft skills model since 2007 to enhance their student marketability. This effort intended to prepare alternative career pathway for university graduates and to prepare strategic networking chances. Many research conducted by the National Higher Learning of Research Institute of Malaysia showed results related to local university graduates unemployment problem. Mohd Fais Mansor et. al. (2007) said that the marketability of a graduate does not only depend on the degree obtained, but rather the emphases of the employers are the soft skills of the graduates.

Furthermore, finding by Morshidi et al. (2004) discovered the correlation between unemployment with work place, weakness in English language proficiency, communication problems and others. Ratna \& Fazal (2008) brought to light the importance of basic skills in language, communication, teamwork and personal attitude in overcoming the challenges of the working world upon graduation. Ambigapathy \& Aniswal (2005) on the other hand, stressed on the importance of creativity and thinking skills in work problem solving to be ingrained in a graduate.

Research finding conducted by the National Higher Learning of Research Institute as mentioned above can be summed up to few soft skills dimension. In this research, Soft Skills Building through Co-curriculum introduced in the National University of Malaysia incorporated seven dimensions. Soft skills that are being studied are communication skills, critical and problem solving skills, teamwork skills, continuous learning and information management skills, entrepreneurship skills, professional moral and ethics as well as leadership skills.

\section{Methodology}

This study focused on 120 undergraduates in the main campus of the university. Questionnaires aided with structured questions on CGPA academic achievements, two dimensions of organization-public relationship and seven dimensions of soft skills were randomly distributed to final-year students from social science and technological science groups. All variables being studied fulfilled the research framework as shown in Figure 1.

\section{Independent Variable $\quad$ Dependent Variable}

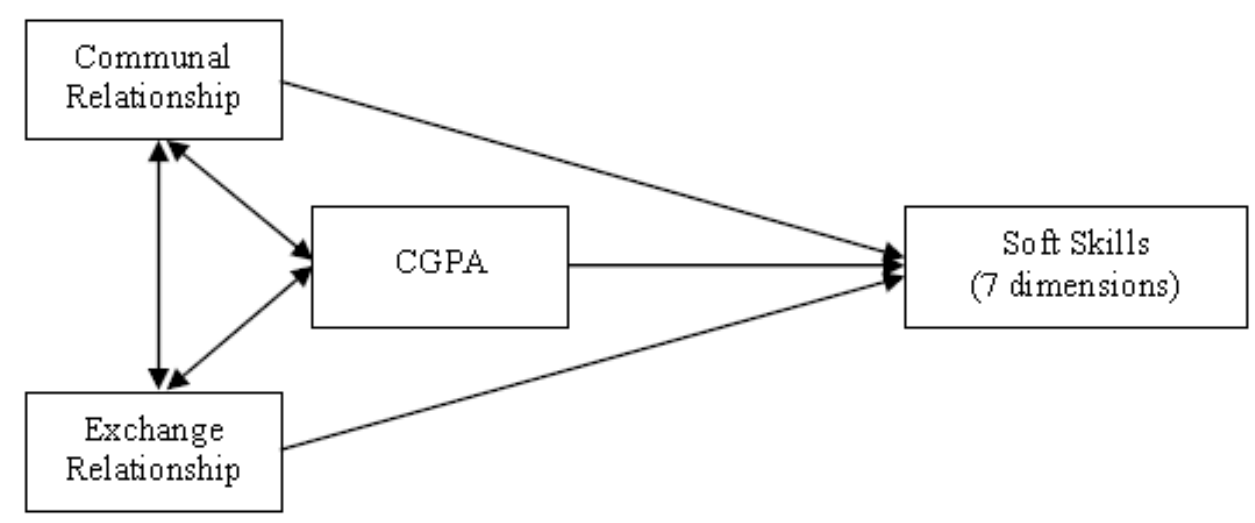

Figure 1. Research framework

This research used survey through the face-to-face interview. In the early stage of this research, the samples selected were voluntary and only directed to 60 students from each group being studied from final year as indicated earlier. Demographic factors are not considered in research sampling. Respondent views were measured using the 5-point Likert's scale whereby scale measurement range on $1=$ very low, $2=$ low, $3=$ medium, $4=$ high, $5=$ very high. Mean scores were derived by adding all scores and divided with the number of details in each variable. Therefore fixed mean scores are between 1 to 5 and more than 3 means inclining to the high side while lesser than 3 means inclining to the low side.

Instrument building for organization-public relationship measurement are based on details suggested by Hon \& Grunig (1999). Four items each for both the measures of communal relationship and exchange relationship as exhibited above were applied in this research study. Instead of 9-point scale, this study adopted the normally used 5-point scale and reliability analysis was conducted in which the values of Alpha for both measures of relationships achieved at .743 and .628 respectively. Four dimensions of independent variables, namely trust, 
satisfaction, commitment and cross control, are not observed in this pilot study. The focus here is the details regarding the communal and exchange relationship.

These two dimensions of university-student relationships are looked closely upon besides the marketability measurements that are evaluated using the seven dimensions soft skills summed up from the National Higher Learning of Research Institute. Details applied in this research for each soft skills dimension are as follows:

S1: Communication skills:

- Ability to convey ideas clearly, effectively and confidently, orally and written

- Ability to practice active listening and give feedback

- Ability to give clear presentation confidently adjusting to the level of listeners

S2: Critical and problem-solving skills:

- Ability to identify and analyze problems in complex and gray situation as well to make a justified evaluation

- Ability to expand and improve thinking skills such as explaining, analyzing and evaluating discussions

- Ability to find ideas and alternative solutions

S3: Teamwork skills:

- Ability to build good relationships, interact with others and effectively work together to achieve a common objective

- $\quad$ Ability to understand and taking turns for the role of leadership and members

- Ability to recognize and respect others characters, behaviors and belief

S4: Continuous learning and information management skills:

- $\quad$ Ability to find and manage information from different and diverse sources

- $\quad$ Ability to accept new ideas and capability of autonomous learning

S5: Entrepreneurship skills:

- Ability to identify business opportunities

- Ability to sketch business plan

S6: Professional moral and ethics

- Ability to understand economic, environmental and socio-culture impact in professional practice

- Ability to analyze and make decisions in solving ethical problems

S7: Leadership skills:

- Knowledge regarding leadership fundamental theories

- Ability to lead a project

Data analysis is done through qualitative method. Beside elaboration on frequency and mean, inferential statistics are used to predict the contributions of each independent variable to dependent variables. Partial correlation was the procedure used. Partial correlation provides a single measure of linear association between two variables while adjusting for the effects of one or more additional variables (Coakes \& Steed, 2007). The partial correlation represents the actual importance of attribute, with the effect of a set of controlling random variables removed. This procedure can identify linear relationship between two variables by controlling other variables that has linear relationship with both test variables. In other words, partial correlation is used in this research to control covariance or control variables effect. Level of confidence for all tests is $95 \%$ with $\alpha=.05$. However for the purpose of controlling type 1 error of Bonferroni method in partial correlation test, $\alpha_{\mathrm{pb}}=.0167$ for three variables test and $\alpha_{\mathrm{pb}}=.0083$ for four variables test were used (Chua, 2009).

\section{Research Findings}

Perception of 115 undergraduates from UKM Bangi Campus was gauged using face-to-face survey method. Referring to Table 1, nearly half of the population are students of social science group (50.4\%) and the rest from the technological science group. Most participants are female (56.3\%) from the Malay ethnic (68.7\%). On average, their age is 22.5 years old. 
Table 1. Respondent Profile

\begin{tabular}{llrr}
\hline Characteristics & Category & Amount & Percentage \\
\hline Academic Group & Social Science & 58 & 50.4 \\
& Technological Science & 57 & 49.6 \\
Gender & Female & 65 & 56.5 \\
& Male & 50 & 43.5 \\
Ethnicity & Malay & 79 & 68.7 \\
& Chinese & 25 & 21.7 \\
Age & Indian & 11 & 9.6 \\
& 21 years old & 7 & 6.1 \\
& 22 years old & 51 & 44.3 \\
& 23 years old & 53 & 46.1 \\
& 24 years old & 4 & 3.5 \\
\hline
\end{tabular}

Their academic achievement are satisfactory with a mean of $M=3.18(S . D .=.316)$ as shown in table 2. In the same table, mean scores for both university-student relationship measurements are presented. Students have good impressions on communal relationship with $M=3.63(S . D .=.627)$; whereas mean score for exchange relationship is $M=2.53(S . D .=.518)$ that is in between medium and low. This indicated that students interviewed expressed their relationship with the university positively.

Table 2. Mean Score of Independent Variables

\begin{tabular}{lrrr}
\hline Academic achievement and relationships & $\mathrm{N}$ & Mean & Standard Deviation \\
\hline CGPA $^{\mathrm{a}}$ & 115 & 3.18 & .316 \\
Communal relationship $^{\mathrm{b}}$ & 115 & 3.63 & .627 \\
Exchange relationship $^{\mathrm{b}}$ & 115 & 2.53 & .518 \\
\hline
\end{tabular}

Note: ${ }^{\mathrm{a}}$ maximum score $=4 ;{ }^{\mathrm{b}}$ minimum score $=1$ and maximum $=5$.

The above-mentioned independent variables were also examined for their differences in terms of ethnicity, gender, and academic group. ANOVA test and $t$-test were applied for this purpose. The test statistics produced all values of $p>.05$ and therefore failed to reject the null hypotheses that no significant differences of CGPA, communal relationship and exchange relationship in terms of the respondent demographic characteristics. In short, the statistical tests can be carried out in totality or with no necessity to segregate the tests by ethnicity, gender, and academic group.

Generally, the students showed satisfactory scores for soft skills that are indicator of their marketability. The mean scores in Table 3 shows that students scored the highest for communication skills with $M=3.51$ (S.D. $=.316)$ and lowest for leadership skills with $M=3.23(S . D .=.215)$. Mean scores for the other five soft skills fall in the range between these two skills. All mean scores ranked between medium and high. In other words, students felt that they are being equipped with marketable capability.

Table 3. Mean Scores for Dependent Variables

\begin{tabular}{lrrr}
\hline Soft skills & N & Mean & Standard Deviation \\
\hline S1: Communication skills & 115 & 3.51 & .316 \\
S2: Critical and Problem Solving Skills & 115 & 3.48 & .265 \\
S3: Teamwork skills & 115 & 3.28 & .520 \\
S4: Continuous learning and information management skills & 115 & 3.26 & .492 \\
S5: Entrepreneurship skills & 115 & 3.23 & .248 \\
S6: Professional moral and ethics & 115 & 3.24 & .493 \\
S7: Leadership skills & 115 & 3.23 & .215 \\
\hline
\end{tabular}

Note: Minimum score $=1$ and maximum $=5$.

First and foremost, all three independent variables are monitored as stated in the first objective. Partial correlation test with $\alpha_{\mathrm{pb}}=.0167$ was used to understand the correlation between the variables. From the values of correlation coefficient and significance presented in Table 4, only relationship between communal relationship and exchange relationship reached confidence level of $95 \%$ whereby $r_{\text {CE.A }}(112)=-.467, p=.000$. CGPA can't 
be proven it's correlation with communal relationship $\left[r_{\mathrm{AC} . \mathrm{E}}(112)=.131\right]$ or exchange relationship $\left[r_{\mathrm{AE} . \mathrm{C}}(112)=\right.$ -.126]. The relationship between the communal relationship and exchange relationship is inverse related on a medium level.

Table 4. Relationships between Independent Variables

\begin{tabular}{lrrr}
\hline Correlate between: & Controlled variable & Coefficient & Significance \\
\hline CGPA \& Communal Relationship & Exchange Relationship & .131 & .083 \\
CGPA \& Exchange Relationship & Communal Relationship & -.126 & .091 \\
Communal \& Exchange Relationships & CGPA & -.467 & .000 \\
\hline
\end{tabular}

Note: Two-tailed test.

The following tests are to identify whether academic achievement or CGPA is directly related with soft skills. Partial test with control on communal and exchange relationship was done on the seven skills discussed. For four variables in this test, $\alpha_{\mathrm{pb}}=.0083$ used for level of confidence $95 \%$ suitable with the purpose to control type 1 error of Bonferroni method. Based on Table 5, there is no single test result that reached significant value lower than $\alpha_{\mathrm{pb}}$ as stated. Therefore all null hypothesis failed to be rejected which means no relationships with soft skills can be proven.

Table 5. Relationship between CGPA and Soft Skills

\begin{tabular}{llrr}
\hline Correlate between: & Controlled variables & Coefficient & Significance \\
\hline CGPA \& S1 & Communal \& Exchange Relationships & .098 & .150 \\
CGPA \& S2 & Communal \& Exchange Relationships & .169 & .037 \\
CGPA \& S3 & Communal \& Exchange Relationships & .001 & .496 \\
CGPA \& S4 & Communal \& Exchange Relationships & .124 & .096 \\
CGPA \& S5 & Communal \& Exchange Relationships & -.146 & .061 \\
CGPA \& S6 & Communal \& Exchange Relationships & .077 & .210 \\
CGPA \& S7 & Communal \& Exchange Relationships & -.024 & .401 \\
\hline
\end{tabular}

Note: One-tailed test.

On the other hand, partial test between communal relationship and soft skill with control of CGPA influence and exchange relationship, 5 from 7 tests resulted in $p<.0083$ namely communication skills, critical and problem solving skills, teamwork skills, continuous learning and information management skills and entrepreneurship skills. All the relationship was seen positively inclined or directly related. From the observation of coefficient correlation, the relationship with teamwork skills is close to strong relationship with $r_{\mathrm{C} 3 \mathrm{AE}}(111)=.693$. Medium relationship can be seen with continuous learning and information management skills $\left[r_{\mathrm{C} 4 . \mathrm{AE}}(111)=.581\right]$, communication skills $\left[r_{\mathrm{C} 1 . \mathrm{AE}}(111)=.447\right]$, and critical and problem solving skills $\left[r_{\mathrm{C} 2 . \mathrm{AE}}(111)=.418\right]$. Relationship with entrepreneurship skills are seen as low $r_{\mathrm{C} 5 . \mathrm{AE}}(111)=.269$.

Table 6. Relationship between Communal Relationship and Soft Skills

\begin{tabular}{llrr}
\hline Relationship between: & Controlled variables & Coefficient & Significance \\
\hline Communal Relationship \& S1 & CGPA \& Exchange Relationship & .447 & .000 \\
Communal Relationship \& S2 & CGPA \& Exchange Relationship & .418 & .000 \\
Communal Relationship \& S3 & CGPA \& Exchange Relationship & .693 & .000 \\
Communal Relationship \& S4 & CGPA \& Exchange Relationship & .581 & .000 \\
Communal Relationship \& S5 & CGPA \& Exchange Relationship & .269 & .002 \\
Communal Relationship \& S6 & CGPA \& Exchange Relationship & .147 & .060 \\
Communal Relationship \& S7 & CGPA \& Exchange Relationship & -.109 & .126 \\
\hline
\end{tabular}

Note: One-tailed test.

In the partial test between exchange relationship and soft skills with the control influence of CGPA and communal relationship, all statistical results showed $p>.0083$ except professional ethics and moral that indicated $p=.001$. This means relationship between exchange relationship with professional ethics and moral inclined to the negative or significantly inverse on level of confidence $95 \%$. Correlation coefficient that is derived is low with $r_{\mathrm{E} 7 . \mathrm{AC}}(111)=-.289$. 
Table 7. Relationship between Exchange Relationship and Soft Skills

\begin{tabular}{llrr}
\hline Relationship between: & Controlled variables & Coefficient & Significance \\
\hline Exchange relationship \& S1 & CGPA \& Communal Relationship & -.045 & .317 \\
Exchange relationship \& S2 & CGPA \& Communal Relationship & -.084 & .187 \\
Exchange relationship \& S3 & CGPA \& Communal Relationship & -.092 & .166 \\
Exchange relationship \& S4 & CGPA \& Communal Relationship & -.119 & .105 \\
Exchange relationship \& S5 & CGPA \& Communal Relationship & -.133 & .081 \\
Exchange relationship \& S6 & CGPA \& Communal Relationship & -.289 & .001 \\
Exchange relationship \& S7 & CGPA \& Communal Relationship & -.099 & .149 \\
\hline
\end{tabular}

Note: One-tailed test.

Based on all the results, we can sum up the relationship between all variables in this research with Figure 2 below. The presentation of this diagram is guided by the research framework discussed before this.

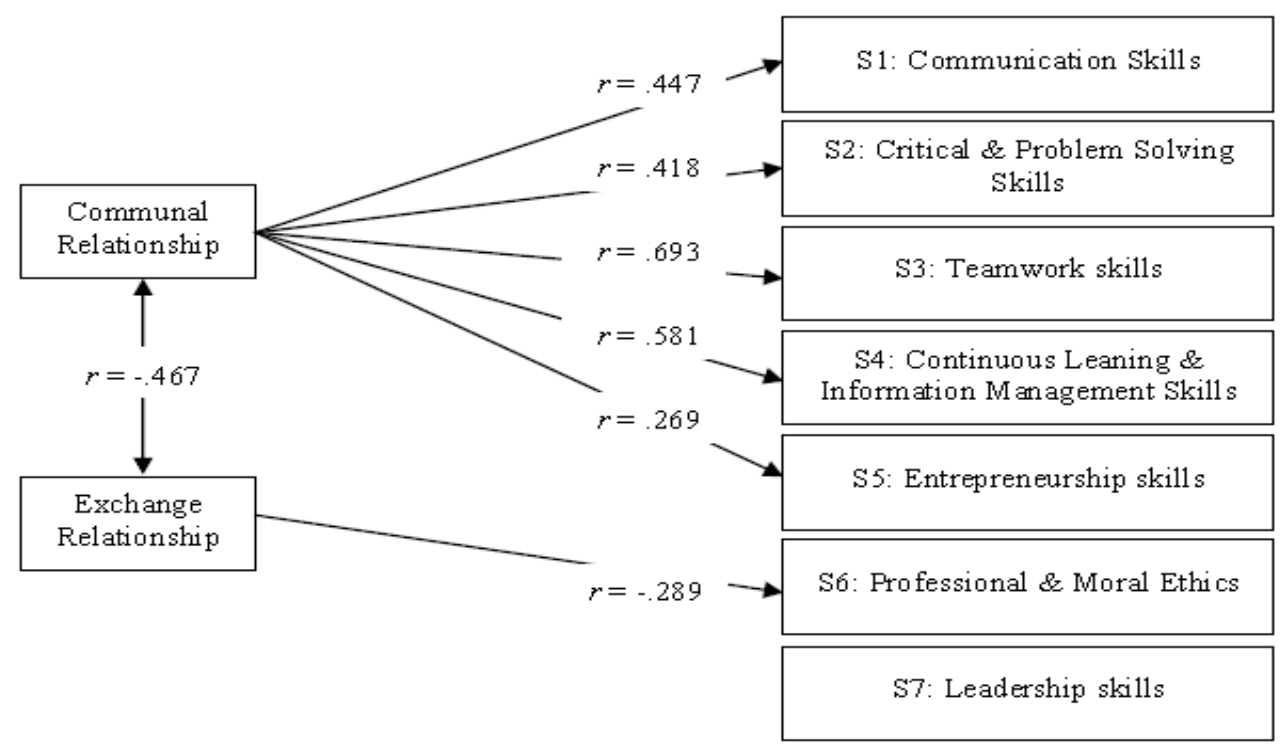

Figure 2. Relationship between university-student relationships with soft skills

\section{Discussion}

From the test done, student academic achievement measured by CGPA (Cumulative grade point average) is found to have no significant correlation with both communal and exchange relationship. CGPA also do not show any significant relationship with all soft skills. Academic achievement as general indicator of students' level of knowledge in certain field relationship with soft skills is uncertain. Therefore, it is more effective to increase soft skills through co-curriculum activities and not through formal education.

On the whole, the findings of this study indicated that the introduction of several of the soft skills in the curriculum and teaching methods have shown some positive and inverse relationships with Hon and Grunig's (1999) measurement of marketability of graduates. However, it is also recognized that not all students will be able to demonstrate excellence across all the soft skills attributes upon graduation. Apart from their level of intelligence that does not show any relationship with the two dimensions identified by Hon and Grunig (1999), perhaps laggards are slow in accumulating soft skills due to other related factors which are not included in this study and this may include type A and type B personality profiles, different socio-demographic backgrounds, peer influence and other dominant intervening variables such as values and norms.

Logically, transformation of the universities' curriculum and teaching approaches do not generate positive results overnight. Even when large sums of money are allocated to the task and academicians are briefed regarding proper implementation of soft skills among graduates, positive achievements will take time. But this does not mean that such transformation effort should be ignored. Changing ingrained attitudes among the human capital may take a sustained effort over an extremely long period. 
Two independent variables in this research, namely communal relationship and exchange relationship were ascertained to have significant inverse relationship. They were proven with respective role in generating certain soft skills dimension. Perspective of communal relationship become a good predictor for five out of seven soft skills dimension, those are communication skills, critical and problem solving skills, teamwork skills, continuous learning and information management skills, and entrepreneurship skills. All the relationships are direct and most are on the medium level. Meanwhile, perspective of exchange relationship was proven to be inversely related with low relationship level only with one dimension that is professional ethics and moral. There is one dimension that has no relationship with any variable that is leadership skills. This could be due to the fact that a student's leadership skills have to be shaped and trained with other methods.

Although leadership skill is considered important for a holistic and well-rounded human capital, the inculcation of leadership values together with the other soft skills attributes does not indicate appropriate and proper implementations. The results of the study implied that leadership skills should be singled out and approached differently for better results. It is important for universities to pay attention to proper implementation of leadership skills among students since future economic growth of a nation depends heavily on far-sighted and capable leaders.

Apart from the dynamic and relevant curriculum and pedagogy introduced to the students, several soft skills need to be imparted differently for better results. This may include team discussion and participation in community activities and services and sports to foster the development of leadership, teamwork and other personal and interpersonal qualities. Hence, this calls for an urgent review of soft skills implementation among the students.

\section{Innovating Learning Environment and Experience}

Relationships can be difficult to measure making public relations practitioners often struggle to demonstrate the influence that public relations activities have on consumer perceptions, evaluations, and behaviors. Current changes are now taking place in the so-called innovation economy. In knowledge economy logic is predominant, while in an innovation economy everything revolves around imagination and creativity rather than land, capital and natural resources. In the innovation economy, the competitive advantage is derived from innovations, whereby creativity becomes the principal driving force behind economic growth. (Sharifah Hapsah S. H. S. 2012). The Malaysian Ministry of Higher Education must make a huge stride to implement a dynamic educational revolution in its effort to empower an integrated and holistic soft skill development for the work market and the country. Its aim is to produce and generate graduates who strike a balance between skills and intelligence.

The roles of universities are consistently being challenged to nurture students at undergraduate and postgraduate in the areas of innovation and technology management regardless of their disciplines. Sharifah Hapsah S. H. S. (2012) asserted that innovation is a change in the thought process for doing something, or the useful application of new inventions or discoveries. In this context the word innovation refers to the design, invention, development and/or implementation of new or altered products, services, processes, systems, organizational structures, or business models for the purpose of creating new value for launching enterprises, and growing existing enterprises, as well as providing financial returns for the university, the region and Malaysia as a whole, and not forgetting to create good communal relationship and exchange relationship between university and students which were ascertained to have significant inverse relationship and were proven with respective role in generating certain soft skills dimension.

Innovation needs people who are always thinking of new things. So university graduates must be equipped with skills to create knowledge and ideas, to acquire or to adapt existing knowledge or ideas or inventions; the skills among others are communication skills, critical and problem-solving skills, teamwork skills, continuous learning and information management skills, entrepreneurship skills, professional and moral ethics and leadership skills being variables in this research context. Universiti Kebangsaan Malaysia is working very closely with Stevens Institutes of Technology, New Jersey that has a rich entrepreneurial environment to implement Steven's innovation model at the undergraduate and postgraduate levels. This model befits this research that emphasises on soft skills to promote a positive relationship with the market.

In the innovation economy universities need to have new competencies that need the support of teaching and learning. They need to reorient their goals, their learning and teaching methodology and their roles as teachers to ensure students are given ample opportunities in an enriched learning environment. Students learn from many people, from many different types of environment. Learning is not just about acquiring knowledge but about values, ethics and professionalism. The academics are the most important asset in this university and the 
university's support for them is as important as their support to the university and the students to realise their full potential to be resourceful and marketable graduates (Sharifah Hapsah S. H. S. 2012)

Subhan, Fauziah and Nabishah (2012) emphasised the fact that universities have to be accountable to the graduates that they produce. The setting of institutions like National Accreditation Board (LAN), Malaysian Qualification Assurance, Audit units and the like, expect universities to show that they have the means and mode of teaching and teaching staffs that can deliver the curriculum of institutions to an acceptable standard to gain the accreditation from the Ministry of Higher Education through the process of quality assurance and auditing. Needless to say universities have to respond to these demands including the need to address maintaining the quality of educators. Universiti Kebangsaan Malaysia has already set up units of teaching and learning under various names, Centre of Learning and Teaching, Centre of Excellence, Educational Development Unit, Centre of Academic Advancement and Academic Staff Development Unit.

The mechanism by which the development units functions to enhance the quality of teaching in universities varies and not much literature on this subject matter thus far. However, Universiti Kebangsaan Malaysia has vigorously embarked on a number of plans to enhance the quality of teaching among other functions for its lecturers. The plans include inculcating lecturers' involvement in doing strategic research. The main purpose of this development is to improve the quality of teaching and learning within various faculties and disciplines. Such a demanding endevour would only succeed with full cooperation from the relevant authorities as well as at the ministerial level (Subhan, Fauziah and Nabishah 2012)

\section{Conclusion}

If soft skills can be the key measurement to graduates marketability, then this research has brought the implication that management of university-public relationship must be looked upon carefully throughout student's learning years. This is parallel with the view of Hon \& Grunig (1999) that said public relations can play its role with communication process happening in long term in an organization. This can be a call for higher education institute to pay attention to relationship with public that are of utmost priority to its organization.

In terms of managing the university-student relationship, creating a symbiosis relationship is crucial for both the university and its students. This refers to an interpersonal association between individuals who are more concerned with what their partner gets rather than what they themselves receive or relationships in which people's primary concern is being responsive to the other person's needs; defining communal relationship. Thus, universities need to build a communal relationship with a public before an exchange can occur. Organizations such as universities must benefit by building a reputation for being concerned about communal relationships and encounter less opposition and more support over the long term from their publics. This is possible because this research has proven that communal relationship can generate certain soft skills dimension and is a good predictor for five out of seven soft skills dimension.

\section{References}

Ambigapathy, P., \& Aniswal, A. G. (2005). University curriculum: An evaluation on preparing graduates for employment. Institut Penyelidikan Tinggi Negara, Universiti Sains Malaysia.

Chang Peng Kee et. Al. (2012). Frame Contention between News Sources and News Media: Framing the Dispute of Teaching Mathematics and Science in English. Asian Social Science, April Special Issue, 8(5). Retrieved from www.ccsenet.org

Chang P.K., \& Musa Abu Hassan. (2006). The advertising-value-equivalent (AVE) method in quantifying economic values of public relations activities: Experience of a public-listed company in Malaysia. Kajian Malaysia, 24, 33-54.

Chua Y.P. (2009). Statistik penyelidikan lanjutan: Ujian regresi, analisis faktor dan analisis SEM (Translation: Advanced Research Statistics: Regression test, factor analysis and SEM analysis). Kuala Lumpur: McGraw Hill.

Coakes, S. J., \& Steed, L. (2000). SPSS version 14.0 for Windows: Analysis without anguish. Australia: John Wiley \& Sons.

Cutlip, S. M., Center, A. H., \& Broom, G. M. (1985). Effective public relations (6th ed.). Englewood Cliffs, NJ: Prentice Hall.

Faridah Ibrahim, Normah Mustaffa, \& Mus Chairil Samani. (2010). Hala Tuju Pengajian Komunikasi dan Media di Malaysia (Translation: Directions of Communication and Media Studies in Malaysia). Kuala Lumpur: Ministry of Higher Education. 
Fatemah Khozaei, Dolapo Amole, Ahmad Sanusi Hassan, \& Zahra Khozaei. (2010, October). Female graduate students' perception of the relationships between the residence hall and the home. Asian Social Science, 6(10). Retrieved from http://www.ccsenet.org/journal/index.php/ass/article/view/6552

Fauziah Ahmad et. Al. (2012). Social Citizenship: Rights, Participation and Responsibilities of Young People. Asian Social Science, April Special Issue, 8(5). Retrieved from www.ccsenet.org

Grunig, J. E. (1992). Communication, public relations, and effective organizations: An overview of the book. In Grunig, J. E. et al. (Eds.), Excellence in public relations and communication management (pp. 1-30). Mahwah, NJ: Lawrence Erlbaum Associates.

Grunig, J. E., \& Huang, Y. H. (2000). From organizational effectiveness to relationship indicators: Antecedents of relationships, public relations strategies and relationship outcomes, Public relations as relationship management: A relational approach to the study and practice of public relations. Mahwah, NJ: Lawrence Erlbaum Associates.

Hon, L., \& Grunig, J. E. (1999). Guidelines for measuring relationships in public relations. Institute for public relations commission on PR measurement and evaluation, University of Florida.

Huang Y. H. (2001). Values of public relations: Effects on organization-public relationships mediating conflict resolution. Journal of Public Relations Research, 13, 265-301. http://dx.doi.org/10.1207/S1532754XJPRR1304_01

Idid, S. A., \& Chang P. K. (2012). The Media and Public Agenda among the Malay and Chinese Communities during the 2008 Malaysian General Elections. Asian Social Science, April Special Issue, 8(5). Retrieved from www.ccsenet.org

Kim, L.L. (2010). An empirical investigation of the impact of supervisory power bases on subordinates. Asian Social Science, 6(7). Retrieved from http://www.ccsenet.org/journal/index.php/ass/article/view/1373/1335

Kim, Y. (2000). Searching for the organization-public relationship: A valid and reliable instrument. Journalism and Mass Communication Quarterly, 78, 799-815.

Ledingham, J. A., \& Bruning, S. D. (Eds.) (2000). Public relations as relationship management: A relational approach to the study and practice of public relations. Mahwah, NJ: Lawrence Erlbaum.

Ministry of Higher Education Malaysia. (2007). National Higher Education Action Plan 2007-2010. Kuala Lumpur: Ministry of Higher Education.

Mohd Fais Mansor, Iskandar Yahya, Mohd Syuhaimi Abd Rahim, \& Aini Hussain. (2007). Penilaian kemahiran insaniah dalamm projek tahun akhir kejuruteraan elektrik, elektronik dan sistem UKM. Paper presented at Seminar Pendidikan Kejuruteraan dan Alam Bina 2007.

Morshidi Sirat, Abdul Majid Mohd, Rosni Bakar, Abdul Aziz Buang, \& Mohd Haflah Piei. (2004). Kajian pencapaian akademik dan kebolehgunaan tenaga siswazah di institusi pengajian tinggi (Translation: Studies on academic achievement and graduates force usability in higher learning institute). Penang: Institut Penyelidikan Tinggi Negara, Universiti Sains Malaysia.

Pendleton, J., \& Kiranjit Kaur. (2008). Developing global public relations practice: Exploring relationships between organizations and the customer stakeholder in Australia and Malaysia. Paper presented at the International Conference on Communication and Media, 14-16 June, Kuala Lumpur, Malaysia.

Ratna Roshida Abdul Razak, \& Fazal Mohamed Sultan. (2008). Kurikulum universiti dan keperluan untuk memperoleh pekerjaan (Translation: University curriculum and need to obtain job). Penang: Institut Penyelidikan Tinggi Negara, Universiti Sains Malaysia.

Samsup, J., Hon, L. C., \& Brunner, B. R. (2004). Organization-public relationships: Measurement validation in a university setting. Journal of Communication Management, 9, 14-27.

Seltzer, T., \& Mitrook, M. (2009). Two sides to every story: Using coorientation to measure direct and meta-perspectives of both parties in organization-public relationships. Public Relations Journal, 3(2), 1-24.

Sharifah Hapsah Syed Hasan Shahabudin. (2010). Preparing graduates for the innovation economy: enrich learning experience. In Subhan, Fauziah and Nabishah (Eds.), Striving for excellence: Governing practice through action research (2010). Bangi: Penerbit Universiti Kebangsan Malaysia

Subhan, Fauziah, \& Nabishah (eds.) (2010). What is action research? In Subhan, Fauziah and Nabishah (Eds.), Striving for excellence: Governing practice through action research (2010). Bangi: Penerbit Universiti Kebangsan Malaysia. 